\title{
METODE REASURANSI QUOTA SHARE TREATY DITINJAU DARI HUKUM PERJANJIAN
}

\author{
Randitya Eko Adhitama ${ }^{1}$
}

\begin{abstract}
Abstrak
This essay discusses the methods of quota share reinsurance treaty review of the applicable treaty law in Indonesia. Writing this essay aims to find out legal protection for client (Insured) when an insurance company (insurer) is making a reinsurance agreement with the company by using the methods of quota share treaty, subject to sanctions such as freezing efforts by the regulator and the responsibility for the insurance company (insurer) in violation of the clause "claim cooperation clause" which are listed in the reinsurance agreement with the method of quota share treaty in handling claims. This research is using the literature research and field research. Results of this study suggest that the government create more regulations to handling claims and required a special institution that can protect the rights of customers in the consumer services in the areas of insurance.
\end{abstract}

Kata Kunci: hukum asuransi, perjanjian, reasuransi, quo share

\section{Pendahuluan}

Pada hakikatnya setiap kegiatan manusia selalu menghadapi berbagai macam kemungkinan atau dengan kata lain setiap manusia selalu menghadapi ketidakpastian yang dapat menimbulkan kerugian atau keuntungan. Ketidakpastian yang dapat menimbulkan kerugian tersebut disebut dengan risiko. Salah satu upaya manusia untuk menanggulangi setiap risiko yang akan dihadapinya adalah dengan jalan mengadakan perjanjian pelimpahan risiko dengan pihak lain. Perjanjian seperti itu disebut dengan perjanjian asuransi atau pertanggungan.

Penanggung atau perusahaan asuransi yang kegiatannya menerima pelimpahan risiko dari pihak lain tentu saja memiliki beban risiko yang lebih berat dibandingkan dengan pihak tertanggung. Hal ini disebabkan karena selain penanggung harus membayar kerugian apabila terjadi klaim, penanggung juga harus meneruskan kegiatan usahanya sendiri.

1 Penulis ada Peneliti pada Laboratorium Hukum, FHUI, alamat korespondensi: randitya_adhitama@yahoo.com. 
Oleh karena itu menurut pasal 271 Kitab Undang-Undang Hukum Dagang, perusahaan asuransi diperbolehkan untuk mengalihkan sebagian atau seluruh risiko yang diterima olehnya untuk dialihkan kembali pada perusahaan asuransi lainnya. Upaya untuk mengalihkan risiko antara suatu perusahaan asuransi kepada perusahaan reasuransi disebut dengan reasuransi.

Dalam rangka mengelola risiko, perusahaan asuransi perlu menentukan bentuk dan metode reasuransi yang tepat. Seperti halnya pada bisnis di sektor lain, maka bisnis asuransi juga memiliki risiko kerugian. Oleh karena itu, dalam upaya menangani risiko tersebut perusahaan dapat menggunakan beberapa cara, yaitu dengan cara menanggung risiko, memperkecil risiko, atau mengalihkan risiko melalui asuransi.

Pada umumnya, perusahaan asuransi dalam menangani risikonya menggunakan cara risk sharing, yaitu dengan reasuransi atau mempertanggungkan kembali risiko yang tidak mungkin mereka tanggung sendiri kepada reasuradur (penanggung ulang/perusahaan reasuransi). Jaminan atau perlindungan reasuransi sangat diperlukan karena berbagai macam alasan, salah satu alasan yang terpenting adalah alasan keamanan (security). Proses pertanggungan inilah yang disebut dengan reasuransi, dengan kata lain reasuransi adalah asuransinya perusahaan asuransi yang berarti bahwa risiko diluar kapasitas mereka dipindahkan kepada reasuradur. Dalam hal melakukan perjanjian reasuransi, terdapat beberapa metode yang dapat digunakan, salah satunya adalah metode quota share treaty.

\section{Pokok Permasalahan}

Dari uraian yang telah dikemukakan, maka muncul beberapa pokok permasalahan sebagai berikut:

1. Bagaimana perlindungan hukum bagi nasabah (tertanggung) apabila perusahaan asuransi (penanggung) yang mengadakan perjanjian dengan perusahaan reasuransi dengan menggunakan metode quota share treaty, dikenakan sanksi berupa pembekuan usaha oleh pihak regulator?

2. Apa tanggung jawab perusahaan asuransi (penanggung) dalam hal melakukan pelanggaran terhadap klausula "claim cooperation clause" yang tercantum dalam perjanjian reasuransi dengan menggunakan metode quota share treaty dalam penanganan klaim? 


\section{Metode Penelitian}

Untuk memudahkan pengertian dalam memperoleh data, maka dalam menyusun skripsi ini penulis menggunakan metode deskriptif, yaitu suatu uraian yang dimaksudkan untuk memperjelas masalah. Dalam menyusun skripsi ini, penulis menggunakan berbagai macam data untuk memudahkan pembahasan, untuk memperoleh data-data tersebut maka penulis melakukan beberapa macam cara, adalah: Pertama, Penelitian Kepustakaan, penelitian ini dilakukan dengan cara membaca dan mempelajari berbagai literatur atau buku-buku ilmiah, peraturan perundang-undangan, media cetak, dan media elektronik khususnya media internet. Kedua, Penelitian Lapangan, penelitian ini dilakukan dengan cara mewawancarai para narasumber yaitu pihak-pihak yang terkait dengan permasalahan yang sedang dibahas.

\section{Tinjauan Umum Mengenai Reasuransi}

\section{A. Sejarah Perkembangan Reasuransi}

Sejarah perkembangan reasuransi tidak dapat dipisahkan dari sejarah perkembangan asuransi, karena reasuransi lahir dari kepentingan asuransi, yaitu untuk measuransikan kembali asuransi yang telah diterimanya. Sejarah reasuransi dimulai pada abad keempat belas masehi, jauh setelah adanya kegiatan asuransi sendiri yang telah ada pada tiga sampai empat ribu tahun sebelum masehi.

Pada masa itu, perdagangan antar bangsa yang dilakukan di sekitar Laut Tengah dan Eropa merupakan salah satu faktor pendukung pesatnya perdagangan dan kegiatan-kegiatan lain yang membantu perdagangan tersebut. Mekanisme perdagangan tersebut mencakup berbagai kegiatan transaksi uang dan modal yang menciptakan bankir dan sistem pembayaran yang dikenal sampai saat ini. Selain itu, mekanisme perdagangan tersebut juga memicu timbulnya kegiatan reasuransi, sebagai akibat dari makin luasnya jangkauan hubungan antar para pedagang yang melampaui wilayahnya masing-masing.

Perjanjian pertama yang dianggap merupakan perjanjian reasuransi adalah perjanjian yang dilakukan pada tanggal 12 Juli 1370, yang dilakukan oleh Giovansi Sacco sebagai pihak tertanggung, Giuliano Grillo sebagai pihak penanggung pertama, Bartolomeo Lemellinino sebagai perantara yang bertindak untuk pihak tertanggung, dan Goffredo di Benavia dan Martino Maruffo sebagai pihak penanggung ulang. Isi perjanjian tersebut adalah bahwa 
penanggung pertama bersedia untuk menanggung asuransi perjalanan laut dari Genoa ke Sluis hanya apabila penanggung pertama yang lain bersedia untuk menanggung risiko untuk bagian yang lebih berbahaya dari seluruh perjalanan. ${ }^{2}$ Kegiatan reasuransi seperti itu kemudian dengan cepat menyebar dan diikuti oleh beberapa pedagang di seluruh Eropa, yaitu Spanyol, Portugal, Prancis, Belanda, Inggris, dan Jerman.

Istilah reasuransi berasal dari bahasa Inggris reinsurance dan bahasa Jerman reassekuranz. Penjelasan mengenai istilah reasuransi baru muncul pada abad ke-16 di Aoven, Prancis. Istilah reasuransi tersebut dijelaskan dalam buku yang berjudul Guidon de la mer. Dalam buku tersebut dijelaskan bahwa seorang penanggung pertama dapat menutup perjanjian asuransi untuk harga yang lebih tinggi atau lebih rendah, apabila ia menyesal dan tidak bersedia memikul risiko yang telah ditutupnya, maka tidak terdapat pilihan lain untuk mencari pihak lain yang bersedia menerima risiko tersebut, karena risiko yang telah ia terima tidak mungkin dapat dilepaskan saja tanpa persetujuan dari pihak tertanggung.

Pada masa itu, praktek reasuransi dilakukan dalam beberapa keadaan, seperti misalnya:

1. Pelaksanaan asuransi kedua dilakukan kepada penanggung kedua karena penanggung pertama meninggal dunia atau pailit.

2. Pelaksanaan asuransi kedua oleh tertanggung atas sebagian nilai pertanggungan karena penanggung pertama tidak mampu menanggung seluruh risiko.

3. Transaksi atau pertukaran bisnis asuransi yang dilakukan di antara para penanggung.

4. Penerimaan pertanggungan secara bersama oleh para penanggung atas suatu obyek yang sama.

5. Measuransikan kembali sebagian dari risiko yang dianggap lebih besar/berbahaya.

Praktek-praktek tersebut berjalan selama beberapa ratus tahun di Eropa. Praktek-praktek tersebut juga diperkuat dengan disahkannya beberapa peraturan yang mengatur mengenai pelaksanaan kegiatan tersebut, diantaranya Ordonances de la Marine 1681 di Prancis, Terminaziono of Venece 1705 di Italia, Hamburg Assekuranz und Habarei Urdzung 1731 di Jerman, Ordinance of Bilbao 1738 di

${ }^{2}$ Sri Rejeki Hartono, "Hukum Asuransi dan Perusahaan Asuransi", (Jakarta: Sinar Grafika, 1995), hal. 42. 
Spanyol, dan Allgemeines Landrecht of the Prusseion States (ALR) 1794 di Prusia.

Perkembangan usaha reasuransi terus dilaksanakan di Eropa, namun pada tahun 1746 di Inggris, usaha reasuransi dilarang dengan dikeluarkannya Gambling Act yang menyebutkan bahwa pelaksanaan reasuransi dianggap melanggar hukum kecuali tertanggung dianggap insolvent, pailit atau meninggal dunia. Apabila salah satu keadaan tersebut terjadi maka asuradur, likuidator, atau pelaksana yang ditunjuk berhak untuk mereasuransikan kembali asuransi yang telah diterima oleh asuradur pertama. ${ }^{3}$ Akan tetapi, Gambling Act ini dicabut pada tahun 1864 karena dengan diberlakukannya Gambling Act ini, banyak para penanggung yang mengalami hambatan dalam menjalankan kegiatan usahanya.

Usaha reasuransi juga mengalami perkembangan pada bentuk usahanya. Bentuk usaha tersebut dapat dibagi menjadi:

1. Underwriter Perorangan (Individual Underwriter)

Pada awalnya, kegiatan asuransi dan reasuransi merupakan kegiatan sambilan yang dilakukan oleh para pedagang di sekitar Laut Tengah. Akan tetapi dalam perkembangannya mulai terasa dibutuhkan keahlian khusus untuk menangani kegiatan ini sehingga muncul underwriter perorangan. Underwriter tersebut mulai melaksanakan pekerjaannya sebagai full time specialist dan memerlukan tempat khusus untuk melaksanakan pertemuan dengan klien-klien mereka. Asosiasi underwriter muncul pertama kali di Inggris yang tergabung dalam Llyod Underwriter di London, yang kemudian disahkan dengan Parliament Act tahun 1871.

Saat ini, Llyod Underwriter biasanya bergabung dalam suatu asosiasi/perusahaan tertentu dan menerima pertanggungan melalui broker dan tidak lagi bertindak sebagai penanggung langsung (direct writing) atas risiko-risiko tertanggung, akan tetapi bertindak sebagai reasuradur/penanggung ulang (reinsurer), baik atas risiko yang berasal dari Inggris maupun dari luar Inggris.

2. Perusahaan Reasuransi (Specialist Reinsurers) atau Reasuradur Profesional.

Perusahaan reasuransi atau specialist reinsurers hanya melakukan kegiatan usaha khusus di bidang reasuransi saja dan hanya mengadakan hubungan dengan perusahaan asuransi sebagai

hal. 5 .

${ }^{3}$ Safri Ayat, "Pengantar Reasuransi", (Jakarta: Akademi Asuransi Trisakti, 2000), 
pemberi bisnis, dan mereka tidak berhubungan langsung dengan pihak penanggung.

Di Indonesia, specialist insurers ini menamakan dirinya sebagai professional reinsurers atau reasuradur profesional. Hal ini dimaksudkan untuk membedakannya dengan asuradur yang juga diizinkan untuk bertindak sebagai reasuradur. Namun oleh pemerintah, penerimaan premi perusahaan reasuransi dari sektor reasuransi dibatasi tidak boleh melebihi $1 / 3$ (sepertiga) dari jumlah penerimaan premi seluruhnya. ${ }^{4}$

3. Perusahaan Asuransi sebagai Reasuransi (Non Specialist Reinsurers)

Kelemahan-kelemahan underwriter perorangan yang dibatasi oleh faktor usia, besarnya nilai pertanggungan, dan dan semakin rumitnya risiko-risiko yang ditawarkan menyebabkan munculnya pemikiran untuk mendirikan sebuah perusahaan asuransi yang kegiatan usahanya tidak akan terhenti dikarenakan kelemahankelemahan yang dimiliki oleh underwriter perorangan tersebut.

Pada awalnya, persaingan di antara perusahaan asuransi sangat ketat dan masing perusahaan asuransi menjaga kerahasiaan nasabahnya masing-masing sehingga tidak terdapat hubungan bisnis di antara perusahaan asuransi yang satu dengan perusahaan asuransi yang lainnya. Akan tetapi, dalam perkembangannya diperlukan adanya suatu kerjasama di antara perusahaan asuransi yang satu dengan yang lainnya. Hal ini disebabkan adanya kekurangan kapasitas untuk menangani risiko di antara perusahaan-perusahaan asuransi tersebut. Kerjasama di antara perusahaan-perusahaan asuransi tersebut melahirkan kegiatan bisnis reasuransi dimana mereka menawarkan kepada pihak lain sebagian dari nilai pertanggungan yang melebihi kapasitas atau retensinya sendiri.

Dalam perkembangan selanjutnya, kegiatan reasuransi menjadi faktor pendorong lahirnya bentuk-bentuk asuransi yang baru karena kegiatan reasuransi melakukan penelitian atas risikorisiko yang baru. Hasil dari penelitian tersebut juga merupakan faktor pendorong bagi pendirian perusahaan baru yang menawarkan proteksi terhadap risiko-risiko yang baru tersebut.

4 Departemen Keuangan, Keputusan Menteri Keuangan tentang Kesehatan Keuangan Perusahaan Asuransi dan Perusahaan Reasuransi, Kepmen. Keuangan No. 224/KMK.017/1993. 


\section{B. Pengertian Reasuransi}

Saat ini, istilah reasuransi dipergunakan secara luas oleh dunia perasuransian. Penggunaan istilah reasuransi tersebut terkadang memiliki pengertian yang berbeda antara yang satu dengan yang lainnya tergantung konteks dan situasi yang sedang dibahas sehingga seringkali menimbulkan kebingungan bagi masyarakat awam maupun para pemula dalam industri asuransi. berikut:

Pengertian reasuransi dapat ditinjau dari beberapa aspek sebagai

1. Tinjauan dari aspek etimologi

Apabila dilihat dari perkembangan bahasa, kata "reasuransi" berasal dari bahasa Belanda "reasurantie". Reasuransi dapat dikatakan sebagai asuransi yang diasuransikan kembali atau measuransikan kembali suatu asuransi yang telah diterima. Reasuransi juga dikenal dengan nama reinsurance dalam bahasa Inggris, reversechering dalam bahasa Belanda, dan ruckversecherung dalam bahasa Jerman.

2. Tinjauan dari aspek teknis

Reasuransi dapat dilihat sebagai suatu mekanisme atau suatu proses kerjasama antara dua penanggung atau lebih dalam kegiatan membagi risiko. Pengertian reasuransi ditinjau dari aspek teknis dapat dilihat dari dua pengertian di bawah ini: ${ }^{5}$

a. Menurut G.F. Michelbacher, reasuransi adalah suatu proses penyertaan asuradur lain dalam suatu perjanjian asuransi antara tertanggung dengan penanggung, dimana penanggung lain tersebut disebut dengan asuradur.

b. Menurut Cockerell H.A.L, reasuransi adalah suatu sistem yang dipergunakan oleh penanggung untuk memberikan seluruh atau sebagian asuransi yang telah diterimanya kepada penanggung lain yang disebut dengan penanggung selang atau reasuradur.

Dari dua pengertian diatas, dapat disimpulkan bahwa reasuransi memiliki fungsi untuk menciptakan suatu proses atas sistem sehingga pihak asuradur dapat mempertanggungkan suatu obyek dengan nilai yang lebih besar dari retensinya sendiri karena adanya dukungan pihak reasuradur.

3. Tinjauan dari aspek hukum

${ }^{5}$ Safri Ayat, Op. Cit., hal. 14. 
Menurut Mollengraff seorang ahli hukum dari Belanda, reasuransi adalah suatu persetujuan atau perjanjian yang dilaksanakan oleh satu penanggung dengan penanggung lainnya yang disebut reasuradur dalam perjanjian dimana pihak penanggung ulang/reasuradur dengan menerima premi yang ditetapkan terlebih dahulu, bersedia memberikan penggantian kerugian penanggung pertama yang wajib membayar kepada tertanggung, dan yang menjadi akibat dari suatu perjanjian pertanggungan yang diadakan antara pihak penanggung pertama dengan pihak tertanggung. ${ }^{6}$

Apabila pengertian tersebut ditelusuri lebih lanjut, maka pengertian tersebut bersumber dari Wetboek van Koophandel En Faillissement Verordening $(W v K)$ atau yang lebih dikenal dengan nama Kitab Undang-undang Hukum Dagang dan Undang-undang Kepailitan (KUHD). Istilah reasuransi berasal dari istilah asuransi yang disebutkan dalam pasal 246 KUHD, yang menyebutkan bahwa:

Suatu perjanjian dengan mana seorang penanggung mengikatkan dirinya kepada seorang tertanggung dengan menerima suatu premi, untuk memberikan penggantian kepadanya karena suatu kerugian, kerusakan, atau kehilangan keuntungan yang diharapkan yang mungkin dideritanya karena suatu peristiwa tak tertentu.

Dari pengertian tersebut, dapat ditemukan beberapa unsur penting yang terdapat dalam pengertian asuransi. Unsur-unsur tersebut adalah sebagai berikut:

a. Perjanjian

Menurut pasal 1774 KUHPerdata, perjanjian asuransi maupun perjanjian reasuransi merupakan perjanjian untung-untungan, yaitu suatu perjanjian mengenai untung ruginya bagi semua pihak dalam perjanjian tersebut, bergantung kepada suatu kejadian yang belum pasti/belum tentu.

Syarat-syarat yang harus dipenuhi untuk sahnya suatu perjanjian asuransi dan reasuransi, sama halnya dengan syarat-syarat sahnya suatu perjanjian yang disebutkan dalam pasal 1320 KUHPerdata. Selain itu, menurut hukum

${ }^{6}$ J.E. Kaihatu, "Asuransi Pengangkutan", (Jakarta: Djambatan, 1967), hai. 170. 
Inggris, suatu perjanjian reasuransi dianggap sah apabila memenuhi persyaratan sebagai berikut: ${ }^{7}$

a) Offer and acceptance, kesepakatan mereka yang mengikatkan dirinya menurut hukum Inggris harus dibuktikan dengan adanya penawaran (offer) dari asuradur dan penerimaan (acceptance) dari reasuradur mengenai suatu obyek yang akan direasuransikan.

b) Consideration, suatu risiko yang akan direasuransikan diterima oleh asuradur dengan persyaratan tertentu.

c) Capacity to enter into the contract, kecakapan untuk membuat suatu perjanjian.

d) Legality, materi atau hal-hal yang diperjanjikan tidak boleh bertentangan dengan ketentuan hukum yang berlaku.

e) Assignment, pengalihan hak dan kewajiban timbul sebagai akibat dari suatu perjanjian seseorang kepada orang lain.

b. Pihak-pihak dalam perjanjian

Perjanjian reasuransi dilakukan antara dua pihak penanggung yang memiliki tingkat pengetahuan yang relatif sama mengenai asuransi. Penanggung pertama disebut dengan asuradur dan penanggung kedua atau penanggung ulang disebut dengan reasuradur. Apabila dalam hal reasuradur mereasuransikan kembali reasuransi yang telah diterimanya, maka reasuradur disebut dengan retrocessor dan hubungannya dengan reasuradur ulang disebut dengan retrocessi.

c. Premi

Dalam perjanjian asuransi, premi merupakan suatu prestasi dari pihak tertanggung kepada pihak penanggung. Apabila dikaitkan dengan perjanjian reasuransi, maka pembayaran premi dilakukan oleh penanggung/perusahaan asuransi (ceding company) kepada penanggung ulang/perusahaan reasuransi (reinsurer). Tanpa adanya pembayaran premi maka tidak akan ada pembayaran klaim.

${ }^{7}$ Safri Ayat, Op. Cit., hal. 18. 
Pembayaran premi dalam perjanjian reasuransi merupakan persyaratan utama dari bentuk perjanjian reasuransi facultative reinsurance maupun treaty reinsurance. Khusus dalam dalam facultative reinsurance, diberlakukan klausula pembayaran premi yang disebut dengan nama Warrantly Payment Clause (WPC) atau Premium Payment Clause.

\section{d. Penggantian}

Penggantian atau pembayaran ganti rugi atas seluruh atau sebagian kerugian yang diderita oleh asuradur hanya dilakukan dengan adanya kewajiban asuradur untuk membayar klaim kepada pihak tertanggung/nasabah. Kewajiban reasuradur untuk membayar klaim hanya akan muncul apabila asuradur wajib membayar klaim kepada tertanggung/nasabah menurut syarat-syarat dan kondisi pertanggungan seperti yang tercantum di dalam polis asuransi.

e. Peristiwa tak tertentu

Peristiwa tak tertentu adalah suatu kejadian/peristiwa di masa yang akan datang yang tidak dapat ditentukan akan terjadi atau tidak akan terjadi. Peristiwa tak tertentu dapat dibedakan menjadi tak tertentu waktu dan tak tertentu peristiwa.

Apabila dilihat dengan cermat, maka terdapat perbedaan yang cukup jelas antara asuransi dan reasuransi. Perbedaan tersebut adalah:

a) Dalam perjanjian asuransi, terdapat perbedaan posisi/ kedudukan antara pihak tertanggung dan pihak penanggung. Pihak tertanggung berada daam posisi yang lebih lemah karena pihak tertanggung memiliki aspek pengetahuan yang lebih sedikit mengenai syarat-syarat dan kondisi pertanggungan yang tercantum dalam polis jika dibandingkan dengan pihak penanggung. Dalam perjanjian reasuransi, kedua belah pihak dianggap mempunyai kedudukan yang sama karena keduanya mengetahui syaratsyarat dan kondisi pertanggungan yang merupakan dasar perjanjian reasuransi. 
b) Dalam perjanjian asuransi, kepentingan yang dipertanggungkan (subject matter of insurance) merupakan kerugian keuangan yang mungkin diderita oleh pihak tertanggung karena hilang atau rusaknya harta benda yang dipertanggungkan. Dalam perjanjian reasuransi, kepentingan yang dipertanggungkan merupakan kewajiban penanggung untuk membayar klaim, sehingga apabila penanggung tidak memiliki kewajiban untuk membayar klaim, maka reasuradur juga tidak memiliki kewajiban untuk membayar kepada asuradur.

c) Bisnis asuransi pada umumnya bersifat nasional. Pada lain pihak, bisnis reasuransi umumnya bersifat internasional.

\section{Prinsip-prinsip Reasuransi}

Bisnis asuransi dan reasuransi berkembang dengan pesat di Amerika Serikat dan Inggris. Hal ini disebabkan adanya kesadaran dan kebutuhan masyarakat yang tinggi akan pentingnya sebuah proteksi atau pengamanan atas harta benda dan dirinya masing-masing. Akan tetapi, baik di Inggris maupun di Amerika Serikat tidak ditemukan adanya peraturan yang mengatur secara khusus mengenai perjanjian asuransi dan reasuransi. Hal-hal yang mengatur mengenai sah atau tidaknya suatu perjanjian asuransi dan reasuransi diatur dalam hukum perjanjian (General Law of Contract).

Di Indonesia, perjanjian asuransi maupun reasuransi diatur dalam Buku Ketiga KUHPerdata. Mengenai prinsip-prinsip asuransi dan reasuransi diatur sebagian di dalam Buku Kesatu KUHD. Apabila ditelusuri dengan cermat, maka dapat disimpulkan terdapat beberapa prinsip khusus yang berlaku dalam reasuransi. Prinsip-prinsip tersebut adalah: ${ }^{8}$

\section{Prinsip Itikad Baik (Utmost Good Faith)}

Maksud dari itikad baik adalah bahwa asuradur mempunyai kewajiban untuk menyampaikan segala hal yang diketahuinya dan yang seharusnya diketahuinya secara lengkap dan benar mengenai obyek yang dipertanggungkan (subject matter of insurance), kondisi dan syarat pertanggungan yang diberlakukan, periode pertanggungan, suku premi (tarif), dan hal-hal lainnya sehingga 
obyek yang direasuransikan tersebut harus sesuai dengan obyek yang diasuransikan (reinsured as original).

Dalam praktek, kadangkala ditemukan pelanggaran dari prinsip itikad baik ini. Beberapa hal yang dianggap sebagai pelanggaran dari prinsip itikad baik ini, adalah:

a. Menyampaikan informasi material yang tidak benar dan tidak lengkap (non disclosure). Informasi material artinya informasi atau keterangan yang penting yang dapat menyebabkan diterima atau ditolaknya suatu penawaran reasuransi dari ceding company oleh reasuradur. Apabila ditinjau dari aspek yuridis, maka yang berhak menentukan apakah suatu informasi atau keterangan bersifat material hanyalah pengadilan. Akan tetapi, berdasarkan pengalaman dari berbagai macam permasalahan, dapat disimpulkan bahwa informasi atau keterangan yang diketahui atau seharusnya diketahui oleh asuradur yang dapat mempengaruhi sikap reasuradur terhadap penerimaan suatu penawaran reasuransi disebut sebagai informasi material.

b. Menyembunyikan informasi (concealment). Apabila pihak asuradur dengan sengaja menyampaikan informasi yang keliru atau dengan sengaja tidak menyampaikan atau menyembunyikan suatu informasi kepada pihak reasuradur, maka suatu perjanjian reasuransi menjadi batal demi hukum jika hal tersebut dapat dibuktikan di kemudian hari. Perbedaan antara concealment dan non disclosure terletak pada faktor kesengajaan dan tidak kesengajaan dari pihak asuradur. Dalam hal concealment, pihak asuradur sengaja tidak memberikan informasi yang keliru atau sengaja tidak menyampaikan informasi kepada pihak reasuradur, sedangkan dalam hal non disclosure, pihak asuradur tidak sengaja menyampaikan informasi yang keliru kepada pihak reasuradur.

c. Menyampaikan informasi yang keliru (innocent misrepresentation).

d. Menyampaikan informasi yang salah dengan maksud mencari keuntungan (fraudulent misrepresentation).

\section{Prinsip Indemnitas (Indemnity)}


Perjanjian reasuransi merupakan perjanjian untuk membayar ganti rugi (contract of indemnity), sepanjang pihak asuradur mempunyai kewajiban untuk membayar klaim sesuai kondisi dan ketentuan yang tercantum dalam polis, oleh karena itu pihak reasuradur juga mempunyai kewajiban untuk membayar beban kerugian yang menjadi bagiannya kepada pihak asuradur.

Dalam perjanjian reasuransi, pihak asuradur harus dapat membuktikan bahwa kerugian yang dideritanya telah memenuhi ketentuan-ketentuan yang berlaku dalam perjanjiannya dengan pihak tertanggung seperti yang tercantum dalam polis asuransi dan tidak melanggar syarat-syarat dan ketentuan dalam perjanjian reasuransi. Pembayaran klaim tersebut harus diselesaikan terlebih dahulu oleh pihak asuradur kepada pihak tertanggung, kemudian pihak asuradur meminta pembayaran kembali kepada pihak reasuradur. Dalam hal pembayaran klaim tersebut jumlah klaim yang harus dibayar cukup besar, maka pihak reasuradur dapat diminta untuk membayar kerugian yang menjadi tanggung jawabnya sebelum pihak asuradur membayar klaim tersebut kepada pihak tertanggung.

Tujuan dari prinsip indemnitas ini adalah untuk mengembalikan pihak tertanggung ke posisi semula sebelum terjadi kerugian.

\section{Prinsip Kepentingan Berasuransi (Insurable Interest)}

Secara harfiah, kepentingan berasuransi dapat diartikan sebagai kepentingan yang dapat diasuransikan atau kepentingan keuangan yang dapat diasuransikan.' Akan tetapi kepentingan keuangan tersebut harus didukung oleh kepentingan hukum, sehingga kepentingan berasuransi dapat disebut sebagai hak yang sah yang dimiliki seseorang untuk mempertanggungkan kepentingan keuangannya pada obyek yang dipertanggungkan.

Dalam hubungan reasuransi, pihak asuradur (ceding company) hanya memiliki insurable interest atas asuransi yang diasuransikannya kembali apabila ia memiliki kewajiban untuk membayar klaim kepada pihak tertanggung sesuai dengan syaratsyarat dan kondisi polis yang dikeluarkannya.

${ }^{9}$ Safri Ayat, Op. Cit., hal. 28. 
Apabila dalam hal pihak asuradur kehilangan insurable interest karena suatu hal, maka pihak reasuradur juga akan kehilangan kewajibannya kepada pihak asuradur.

\section{Prinsip Subrogasi (Subrogation)}

Prinsip subrogasi ini diatur dalam Pasal 284 KUHD yang menyatakan bahwa:

Seorang penanggung yang telah membayar kerugian suatu barang yang dipertanggungkan, menggantikan si tertanggung dalam segala hak yang diperolehnya terhadap orang-orang ketiga berhubung dengan menerbitkan kerugian tersebut, dan si tertanggung itu adalah bertanggungjawab untuk setiap perbuatan yang dapat merugikan hak si penanggung terhadap orang-orang ketiga itu.

Subrogasi dalam asuransi merupakan subrogasi menurut undang-undang. Oleh karena itu prinsip subrogasi hanya dapat dijalankan apabila pihak tertanggung memiliki hak-hak terhadap pihak penanggung dan selain itu pihak tertanggung juga masih memiliki hak-hak terhadap pihak ketiga; dan hak-hak tersebut timbul karena terjadi/adanya suatu kerugian. ${ }^{10}$ Pada umumnya prinsip subrogasi ini secara tegas diatur dalam syarat-syarat polis.

Dalam reasuransi, sebenarnya prinsip subrogasi ini tidak diberlakukan kembali karena hal tersebut sudah dilaksanakan dalam perjanjian asuransi antara pihak tertanggung dan penanggung. Tujuan dari prinsip subrogasi ini adalah untuk mempertahankan prinsip indemnitas, yaitu untuk mengembalikan pihak tertanggung ke posisi semula sebelum terjadi kerugian.

Subrogasi yang diterima oleh asuradur dari pihak ketiga akan mengurangi jumlah kerugian atau klaim dan perhitungan klaim dari asuradur kepada pihak reasuradur, oleh karena itu pihak reasuradur harus telah memperhitungkan subrogasi tersebut.

5. Prinsip Kontribusi (Contribution)

10 Emmy Pangaribuan Simanjuntak, "Hukum Pertanggungan Kerugian Pada Umumnya, Kebakaran dan Jiwa", (Yogyakarta: Seksi Hukum Dagang Fakultas Hukum Universitas Gajah Mada, 1975), hal. 96. 
Dalam asuransi, prinsip kontribusi dapat berlaku antara pihak tertanggung dan penanggung dalam hal terjadi pertanggungan di bawah harga atau antara sesama asuradur apabila mereka mempertanggungkan obyek pertanggungan yang sama dengan syarat-syarat dan kondisi pertanggungan yang sama pula. Tujuan dari prinsip ini sama dengan tujuan dari prinsip subrogasi, yaitu untuk mempertahankan prinsip indemnitas.

6. Prinsip Senasib Sepenanggungan (Follow The Fortune of Insurance Company)

Dalam hubungan reasuransi, pihak reasuradur dapat dikatakan mengikuti nasib/keberuntungan (follow the fortune) pihak asuradur, dalam nasib baik maupun nasib buruk. Untuk melindungi kepentingan dan membatasi kewenangan pihak asuradur yang berlebihan, maka pihak reasuradur dapat menerapkan beberapa ketentuan sebagai berikut:

\section{a. Claim Cooperation Clause}

Hal ini berupa klausula dalam perjanjian reasuransi (treaty maupun facultative) yang mewajibkan asuradur untuk bekerjasama dengan reasuradur untuk menangani klaim-klaim tertentu.

\section{b. Claim Control Clause}

Dalam klausula ini, asuradur akan bertindak sebagai penentu dalam setiap proses klaim termasuk dalam penunjukkan adjuster dan memutuskan apakah suatu klaim dibayar atau tidak. Asuradur hanya berfungsi sebagai penghubung antara tertanggung dan reasuradur.

\section{c. Ex-Gratia Payment}

Dalam beberapa kasus, dapat terjadi bahwa klaim yang diajukan tertanggung sebenarnya tidak valid atau tidak dijamin menurut kondisi dan syarat-syarat pertanggungan yang tercantum dalam polis asuransi. Namun dengan berbagai macam pertimbangan, klaim tersebut tetap harus dibayarkan. Untuk menghindari kewenangan asuradur yang berlebihan dalam pembayaran klaim ex-gratia, maka seringkali asuradur mengecualikan pembayaran klaim secara ex-gratia dalam perjanjian reasuransi atau dengan kata lain untuk setiap kasus harus dimintakan izin terlebih dahulu dari pihak reasuradur. 


\section{Bentuk Reasuransi}

Metode/bentuk reasuransi adalah cara yang dilakukan oleh asuradur untuk menempatkan bisnis reasuransi. Secara garis besar metode reasuransi dibagi menjadi dua macam:

\section{Reasuransi Fakultatif (Facultative Reinsurance)}

Reasuransi fakultatif merupakan salah satu metode/bentuk reasuransi yang tertua. Bentuk reasuransi ini biasa dipergunakan untuk asuransi kebakaran dan kecelakaan karena sifat dari reasuransi ini didasarkan atas adanya suatu kebebasan untuk memilih bagi para pihak yang melakukan perjanjian reasuransi. ${ }^{11}$ Metode/bentuk reasuransi ini dibagi menjadi dua macam, yaitu sebagai berikut:

\section{a. Reasuransi Fakultatif Biasa}

Dalam perjanjian reasuransi semacam ini, pihak asuradur mempunyai kebebasan untuk menawarkan atau tidak menawarkan suatu bisnis reasuransi kepada pihak reasuradur dan pihak reasuradur juga mempunyai kebebasan untuk menerima atau tidak menerima penawaran bisnis reasuransi dari pihak asuradur. Keuntungan dari bentuk reasuransi ini adalah:

a) Nilai pertanggungan melebihi dari kapasitas perjanjian;

b) Okupasi obyek pertanggungan yang akan di reasuransikan tidak termasuk/dikecualikan di dalam perjanjian;

c) Untuk menjaga perjanjian;

d) Meningkatkan kerjasama antara sesama asuradur.

Kerugian atau kekurangan dari bentuk asuransi ini adalah:

a) Pelaksanaannya memerlukan waktu yang lama;

b) Pengelolaan bisnis tersebut memerlukan biaya administrasi yang besar.

${ }^{11}$ Sri Rejeki Hartono, Op. Cit., hal. 171. 


\section{b. Reasuransi Facultative Obligatory}

Reasuransi semacam ini bersifat fakultatif bagi pihak asuradur untuk menawarkan atau tidak menawarkan bisnis kepada reasuradur. Akan tetapi, apabila bisnis tersebut telah ditawarkan kepada reasuradur maka reasuradur wajib untuk menerimanya. Keuntungan dari bentuk reasuransi ini adalah:

a. Asuradur telah mempunyai bantuan yang pasti dari pihak reasuradur sehingga bantuan tersebut dapat digunakan kapan saja oleh asuradur;

b. Reasuradur dapat memperoleh gambaran yang lebih jelas menegani risiko-risiko yang diterimanya;

c. Komisi asuransi yang diberikan oleh reasuradur lebih kecil jika dibandingkan dengan metode treaty proporsional sehingga reasuradur dapat memperoleh premi yang lebih banyak.

Kerugian atau kekurangan dari bentuk reasuransi ini adalah:

a. Asuradur memperoleh komisi yang lebih kecil;

b. Memakan biaya administrasi yang besar.

\section{Traktat Reasuransi (Reinsurance Treaty)}

Reinsurance treaty atau reasuransi berdasarkan perjanjian adalah suatu perjanjian dasar yang mengatur hubungan reasuransi antara pihak asuradur dengan pihak reasuradur secara terus menerus sampai perjanjian tersebut disepakati oleh kedua belah pihak. ${ }^{12}$ Perjanjian tersebut menjadi dasar pengaturan hubungan hukum di antara para pihak yang menyangkut hak dan kewajiban masing-masing pihak.

Secara garis besar, bentuk reasuransi semacam ini dapat dibedakan menjadi dua macam, adalah:

\section{a. Reasuransi Proporsional}

Dalam bentuk ini, terdapat perbandingan yang sama antara hak untuk memperoleh premi dan kewajiban untuk membayar klaim di antara pihak asuradur dan reasuradur. Bentuk reasuransi ini dapat dibagi lagi menjadi dua macam, adalah:

${ }^{12}$ Ibid., hal. 176. 


\section{Quota Share Treaty}

Quota share treaty adalah suatu perjanjian reasuransi dengan suatu persentase tertentu dari masing-masing dan setiap risiko yang diterima oleh penanggung pertama harus dialokasikan kepada penanggung ulang.

Dalam metode/bentuk reasuransi ini, maka bagian dari asuradur dan reasuradur ditentukan berdasarkan persentase yang tetap dari kapasitas atau treaty limit dari setiap risiko.

\section{Surplus}

Reasuransi surplus adalah suatu perjanjian reasuransi yang mewajibkan kepada asuradur untuk segera mengalihkan risiko kepada reasuradur apabila risiko tersebut melebihi batas yang telah disetujui dan reasuradur telah terikat untuk menerima risiko tersebut. ${ }^{13}$ Dalam reasuransi ini, reasuradur hanya akan terlibat apabila retensi sendiri pihak asuradur sudah terpenuhi.

\section{b. Reasuransi Non Proporsional}

Reasuransi non proporsional mengatur bahwa pihak reasuradur mempunyai kewajiban membayar ganti rugi yang melebihi batas tertentu, sehingga reasuradur tidak memiliki kewajiban untuk membayar ganti rugi apabila kerugian tersebut tidak melebihi batas yang besarnya telah disepakati dan dicantumkan di dalam perjanjian. Tujuan utama dari reasuransi ini adalah untuk menghindari kerugian itu sendiri. Reasuransi non proporsional dapat dibagi menjadi empat jenis, adalah:

\section{Working Cover Excess of Loss}

Maksud dari reasuransi ini adalah pihak reasuradur hanya terlibat dalam hal pembayaran klaim apabila klaim tersebut telah melebihi retensi sendiri dari pihak asuradur. Keuntungan dari working cover excess of loss adalah:

a. Untuk melindungi retensi sendiri dalam proporsional treaty;

b. Penerimaan premi tidak perlu dibagi secara proporsional kepada reasuradur, sehingga menguntungkan pihak asuradur;

c. Biaya administrasi yang sedikit;

d. Penyelesaian klaim dari pihak reasuradur didasarkan atas pembayaran tunai; 
e. Menghemat biaya premi fakultatif.

Kerugian dari working cover excess of loss adalah:

a. Asuradur harus membayar premi terlebih dahulu sebelum ia mengumpulkan premi asuransinya;

b. Tidak ada pengembalian premi reasuransi.

\section{Stop Loss (Excess of loss Ratio)}

Seiring dengan berjalannya waktu, apabila jumlah pembayaran klaim yang merupakan retensi sendiri pihak asuradur sudah mencapai batas tertentu maka pihak asuradur akan menghentikan pembayaran klaim tersebut dan pihak reasuradur wajib mengambil alih kewajiban dari pihak asuradur untuk membayar klaim.

\section{Catastrophe Excess of Loss}

Jenis reasuransi ini dilakukan untuk menutup akumulasi kerugian-kerugian (accumulation of losses) yang disebabkan oleh suatu kejadian yang sifatnya catastrophe (besar sekali/bencana alam) yang dapat menimbulkan kerugian yang sangat besar.

\section{Common Account Excess of Loss}

Jenis reasuransi ini memberikan proteksi terhadap keseluruhan hasil underwriting suatu perusahaan pada tahun tertentu. Untuk itu diperlukan data-data mengenai hasil underwriting yang diperoleh minimal sejak lima tahun yang silam. Data-data tersebut memperlihatkan loss ratio dan tren dari loss ratio tersebut.

\section{v. Pembahasan}

\section{A. Perjanjian Asuransi}

Asuransi dalam pengertian hukum mengandung arti sebagai suatu jenis perjanjian. Meskipun demikian, perjanjian asuransi itu mempunyai tujuan yang spesifik dan pasti. Tujuan tersebut terdapat pada manfaat ekonomi bagi kedua belah pihak yang mengadakan perjanjian. Di dalam KUHPerdata, perjanjian asuransi dikategorikan ke dalam bentuk perjanjian untung-untungan yang diatur dalam pasal 1774 KUHPerdata. ${ }^{14}$ 
Penerapan perjanjian asuransi sebagai perjanjian untung-untungan seperti yang dijelaskan di dalam KUHPerdata tidaklah tepat. Perjanjian untung-untungan mempunyai kecenderungan yang besar pada pertaruhan atau perjudian. Lain halnya dengan perjanjian asuransi yang pada dasarnya sudah memiliki tujuan yang pasti. Tujuan tersebut adalah untuk mengalihkan risiko yang sudah ada yang berkaitan pada kemanfaatan ekonomi tertentu sehingga tetap berada pada posisi yang sama. Posisi atau keadaan ekonomi yang sama tersebut dipertahankan dengan memperjanjikan pemberian ganti rugi karena terjadinya suatu peristiwa yang belum pasti. Jadi perjanjian asuransi itu diadakan dengan maksud untuk memperoleh suatu kepastian atas kembalinya keadaan ekonomi seperti semula sebelum terjadinya suatu peristiwa.

Batasan perjanjian asuransi secara formal diatur dalam pasal 246 KUHD. ${ }^{15}$ Pasal tersebut mengatur suatu hubungan hukum dengan syarat tertentu yang harus dipenuhi bagi suatu perjanjian sehingga perjanjian tersebut dapat disebut sebagai perjanjian asuransi. Batasan perjanjian yang diatur dalam pasal 246 KUHD tersebut merupakan indikator bahwa perjanjian asuransi pada dasarnya adalah perjanjian yang mempunyai tujuan memberi ganti kerugian sesuai dengan asas indemnitas adalah:

1. Asuransi atau pertanggungan adalah suatu perjanjian, dimana seorang penanggung mengikatkan diri kepada seorang tertanggung dengan menerima suatu premi untuk memberikan penggantian kepadanya karena suatu kerugian, kerusakan, atau kehilangan keuntungan yang diharapkan yang mungkin akan dideritanya karena suatu peristiwa yang tidak tertentu.

14 Suatu perjanjian untungan-untungan adalah suatu perbuatan yang hasilnya, mengenai untung ruginya, baik bagi semua pihak, maupun bagi sementara pihak, bergantung pada suatu kejadian yang belum tertentu.

Demikian adalah:

Perjanjian pertanggungan;

Bunga cagak hidup;

Perjudian dan pertaruhan.

Perjanijan yang pertama diatur di dalam Kitab Undang-Undang Hukum Dagang.

15 Asuransi atau pertanggungan adalah suatu perjanjian dengan mana seorang penanggung mengikatkan diri kepada seorang tertanggung, dengan menerima suatu premi, untuk memberikan penggantian kepadanya karena suatu kerugian, kerusakan atau kehilangan keuntungan yang diharapkan, yang mungkin akan dideritanya karena suatu peristiwa tidak tertentu. 
2. Asuransi atau pertanggungan adalah suatu perjanjian, dimana penanggung dengan menikmati suatu premi mengikatkan dirinya terhadap tertanggung untuk membebaskannya dari kerugian karena kehilangan kerugian atau ketiadaan keuntungan yang diharapkan yang dapat dideritanya karena suatu kejadian yang tidak pasti.

Pada dasarnya, perjanjian asuransi merupakan suatu perjanjian yang memiliki ciri-ciri khusus jika dibandingkan dengan perjanjian lainnya. Ciri-ciri tersebut adalah: ${ }^{16}$

1. Perjanjian asuransi adalah perjanjian yang bersifat aleatair, artinya adalah perjanjian ini merupakan perjanjian yang masih menggantungkan prestasi penanggung pada suatu peristiwa yang belum pasti, sedangkan pihak tertanggung sudah memiliki prestasi yang pasti;

2. Perjanjian asuransi adalah perjanjian bersyarat, artinya adalah perjanjian ini merupakan suatu perjanjian yang prestasi penanggung hanya akan terlaksana apabila syaratsyarat yang ditentukan dalam perjanjian telah dipenuhi;

3. Perjanjian asuransi adalah perjanjian yang bersifat sepihak, artiny adalah perjanjian ini menunjukkan bahwa hanya satu pihak saja yang memberikan janji, yaitu pihak penanggung. Dalam hal ini penanggung memberikan janji akan mengganti suatu kerugian apabila pihak tertanggung sudah membayar premi dan polis sudah berjalan, sebaliknya tertanggung tidak menjanjikan sesuatu;

4. Perjanjian asuransi adalah perjanjian yang bersifat pribadi, artinya adalah bahwa kerugian yang timbul harus merupakan kerugian orang perorangan (pribadi), bukan kerugian kolektif. Kerugian yang bersifat pribadi itulah yang nantinya akan diganti oleh pihak penanggung;

5. Perjanjian asuransi adalah perjanjian yang melekat pada syarat penanggung. Pada hakikatnya, syarat dan kondisi perjanjian hampir seluruhnya ditentukan oleh pihak penanggung dan bukan karena adanya kata sepakat yang murni;

6. Perjanjian asuransi adalah perjanjian dengan syarat itikad baik yang sempurna, artinya adalah perjanjian asuransi merupakan perjanjian dengan keadaan bahwa kata sepakat

${ }^{16}$ Sri Rejeki Hartono, Op. Cit., hal. 92. 
dapat tercapai apabila masing-masing pihak mempunyai pengetahuan yang sama mengenai fakta, sehingga dapat terbebaskan dari cacat-cacat yang tersembunyi.

Pelaksanaan perjanjian asuransi ditandai dengan pemenuhan kewajiban penanggung untuk meberikan ganti rugi kepada pihak tertanggung. Pemenuhan kewajiban tersebut tidak segera diberikan secara otomatis, melainkan harus memenuhi asas dan syarat-syarat tertentu. Syarat-syarat tersebut, yaitu:

1. Adanya peristiwa tidak tertentu;

2. Hubungan sebab akibat;

3. Apakah terdapat hal-hal yang memberatkan risiko;

4. Apakah terdapat cacat pada barang yang diasuransikan;

5. Kesalahan tertanggung;

6. Nilai yang diasuransikan.

\section{B. Perjanjian Reasuransi}

Reasuransi adalah suatu perjanjian yang dilakukan oleh pihak perusahaan asuransi (ceding company) sebagai pihak pertama dengan pihak perusahaan reasuransi sebagai penanggung ulang, yaitu pihak kedua. Pihak pertama menyetujui untuk memindahkan dan pihak kedua menyetujui untuk menerima suatu bagian yang ditentukan dari suatu risiko sebagaimana ketentuan yang diperjanjikan dalam perjanjian.

Perjanjian reasuransi muncul setelah adanya perjanjian asuransi antara pihak tertanggung (nasabah) dengan pihak penanggung pertama (perusahaan asuransi/ceding company). Meskipun demikian, di dalam perjanjian reasuransi, tertanggung tidak mempunyai kedudukan hukum apapun secara langsung, sehingga pihak tertanggung juga tidak mempunyai hak apapun di dalam perjanjian reasuransi. Pihak tertanggung adalah pihak di dalam perjanjian asuransi sehingga mempunyai hak berdasarkan kepentingan terhadap pihak penanggung pertama, tetapi tidak demikian di dalam perjanjian reasuransi. Akibat dari hal tersebut, pihak tertanggung tidak dapat mengajukan klaim atau tuntutan apapun terhadap perjanjian reasuransi. Jadi perjanjian reasuransi hanya ditutup dan melibatkan pihak-pihak tertentu saja yaitu antara perusahaan-perusahaan asuransi dengan perusahaan reasuransi. 


\section{Keterlibatan Pihak Tertanggung (nasabah) Dalam Perjanjian Reasuransi}

Secara formal, perjanjian asuransi hanya melibatkan dua pihak saja yaitu perusahaan asuransi sebagai penanggung dan perusahaan reasuransi sebagai penanggung ulang. Akan tetapi, mengingat kepentingan tertanggung serta kedudukannya dalam perjanjian asuransi, maka tertanggung dapat terlibat dalam perjanjian reasuransi tersebut.

Konsep keterlibatan pihak tertanggung di dalam perjanjian reasuransi dapat dijabarkan sebagai berikut:

\section{Penerapan pasal 1317 KUHPerdata}

Pasal 1317 KUHPerdata ${ }^{17}$ mengandung suatu ketentuan sebagai pengecualian terhadap ketentuan umum bahwa perjanjian hanya berlaku bagi para pihak yang membuatnya. Penerapan ketentuan pasal 1317 KUHPerdata dapat dilaksanakan dengan sempurna apabila dipenuhi salah satu syarat berikut ini, adalah:

a. Adanya suatu penetapan janji yang dibuat oleh seseorang untuk dirinya sendiri; atau

b. Adanya suatu pemberian janji yang diberikan kepada orang lain.

Menurut Prof. Dr. Mariam Darus Badrulzaman, ${ }^{18}$ janji untuk pihak ketiga tersebut merupakan suatu penawaran (offerte) yang dilakukan oleh pihak yang meminta diperjanjikan hak (stipulator) kepada pihak ketiga. Pihak yang meminta diperjanjikan haknya (stipulator) tersebut tidak dapat menarik kembali perjanjian itu apabila pihak ketiga telah menyatakan menerima perjanjian itu. Tindakan penawaran yang dilakukan oleh stipulator kepada pihak ketiga menunjukkan suatu tindakan yang bersifat aktif, sehingga dapat mempengaruhi perjanjian pokok itu sendiri dengan telah diterimanya penawaran tersebut.

17 Lagi pun diperbolehkan juga untuk meminta ditetapkannya suatu janji guna lkepentingan seorang pihak ketiga, apabila suatu penetapan janji yang dibuat oleh seorang untuk dirinya sendiri, atau suatu pemberian yang dilakukannya kepada seorang lain, memuat suatu janji yang seperti itu. Siapa yang telah memperjanjikan sesuatu seperti itu, tidak boleh menariknya kembali, apabila pihak ketiga tersebut telah menyatakan hendak mempergunakannya.

${ }^{18}$ Mariam Darus Badrulzaman, Kitab Undang-Undang Hukum Perdata Buku III Hakum Perikatan dengan Penjelasan, (Bandung: Alumni, 1983), hal. 96. 
Di dalam perjanjian reasuransi baik di dalam perjanjian pokok maupun di dalam syarat-syarat tambahan tidak menunjukkan adanya suatu janji terhadap pihak ketiga (dalam hal ini pihak tertanggung). Jadi dengan demikian akan terlihat jelas bahwa perjanjian reasuransi merupakan suatu perjanjian yang berdiri sendiri dan terlepas dari perjanjian asuransi. Pada perjanjian asuransi, hubungan hukum terjadi antara penanggung dengan tertanggung atas kepentingan tertanggung, yaitu kerugian yang diderita tertanggung. Sedangkan pada perjanjian reasuransi, hubungan hukum terjadi antara penanggung dengan penanggung ulang atas kepentingan penanggung yaitu kewajiban dan tanggung jawabnya untuk membayar ganti rugi kepada tertanggung.

2. Konsep hubungan mata rantai

Suatu perjanjian lain hanya dapat terjadi apabila sudah dilakukan suatu perjanjian sebelumnya, jadi perjanjian pertama merupakan alasan diadakannya perjanjian kedua. Dalam konteks ini, perjanjian asuransi merupakan dasar diadakannya perjanjian reasuransi. Sehingga dapat disimpulkan bahwa perjanjian reasuransi muncul karena adanya perjanjian asuransi.

Konsep ini dapat digunakan untuk menjawab dasar hukum perjanjian asuransi terhadap perjanjian reasuransi. Akan tetapi konsep ini tidak relevan untuk menjawab seberapa jauh tertanggung dapat masuk atau mempengaruhi perjanjian reasuransi itu sendiri. Jadi kedua perjanjian tersebut masing-masing tetap merupakan suatu perjanjian dengan ciri, isi, dan para pihak yang berbeda. Meskipun demikian Dr. Klaus Gerathewoh $l^{19}$ menyatakan bahwa kemungkinan tersebut dapat terjadi dalam praktek, adalah:

a. Di Amerika, dengan menggunakan klausula insolvency dapat diterapkan pada penanggung ulang membayarkan kepada penerima atau likuiditas apabila penanggung pertama mengalami pailit atau likuidasi.

b. Pada kasus-kasus yang jarang dapat mempergunakan klausula cut-through (potong-lintas) dengan penanggung pertama sehingga dengan demikian dapat memberikan hak kepada tertanggung untuk berusaha menyelesaikan secara

19 Klaus Gerathewohl, et al, "Reinsurance Principles and Practice, vol. II", (Federal Republic of Germany: Verlag Versicherungs Wirtschaft C.V, Karlsruhe, 1982), hal. 742 . 
langsung kepada penanggung ulang untuk bagian yang memang menjadi bagiannya.

3. Dasar hukum kedudukan tertanggung sesuai dengan asuransi atas tanggung jawab hukum

Asuransi terhadap tanggung jawab menurut hukum memiliki pengertian bahwa penanggung pertama melaksanakan perjanjian reasuransi selayaknya seseorang atau sebuah lembaga yang secara hukum harus bertanggung jawab atas akibat yang timbul dari perbuatan hukum tertentu, lalu kemudian mengasuransikan tanggung jawabnya tersebut.

Secara umum dapat dikatakan bahwa hubungan antara asuransi dan reasuransi merupakan suatu hubungan kerjasama yang saling bergantung satu sama lain dan keterlibatan yang dilakukan oleh para pihak atas dasar timbal balik. Hubungan hukum tersebut terjadi dalam berbagai macam bentuk perjanjian reasuransi. Jadi secara teknis peran reasuransi terhadap kegiatan asuransi adalah melindungi penanggung pertama (ceding company) terhadap insolvency (ketidakmampuan untuk melakukan pembayaran) yang dapat menjamin stabilitas usaha asuransi pada umumnya.

Tujuan reasuransi semata-mata bersifat teknis yang dapat meletakkan perusahaan asuransi pada posisi yang aman dalam hal pertanggungjawaban kepada tertanggung, karena perihal mengenai konsekuensi material pasti terjamin oleh reasuransi. Oleh karena itu kemampuan untuk membayar pasti dapat dijaga oleh perusahaan asuransi yang bersangkutan demi kepentingan para nasabah yang telah mempercayakan risikonya kepada perusahaan asuransi.

\section{Kewajiban Tertanggung Terhadap Penanggung (Ceding Company)}

Dalam suatu perjanjian asuransi, terdapat suatu kewajiban bagi pihak tertangung terhadap pihak penanggung. Kewajiban tersebut dikenal dengan istilah warranties. Warranties dapat dikatakan sebagai suatu janji yang merupakan bagian dari kontrak yang apabila terjadi pelanggaran yang menimbulkan kerugian, maka pihak yang dirugikan dapat menuntut atas kerugian tersebut.

Warranties dalam perjanjian asuransi merupakan kondisi yang fundamental sehingga jika terjadi pelanggaran, maka pihak yang dirugikan dapat membatalkan perjanjian tersebut. Warranties yang harus dipenuhi oleh pihak tertanggung, adalah: 
a. Akan melakukan sesuatu; atau

b. Tidak akan melakukan sesuatu; atau

c. Suatu fakta yang dinyatakan ada; atau

d. Suatu fakta yang dinyatakan tidak akan ada.

Alasan adanya warranties adalah:

1. Untuk meyakinkan bahwa suatu aspek akan dilakukan atau tidak dilakukan atau harus ada atau tidak boleh ada yang menjadikan bahan pertimbangan bagi penanggung;

2. Untuk meyakinkan bahwa dampak risiko tinggi tidak timbul tanpa adanya pengetahuan penanggung karena akan mempengaruhi premium rate.

Warranties dapat dibagi menjadi 2 macam, adalah:

1. Express Warranty

Adalah warranty yang dinyatakan dalam polis dengan menyebutkan bahwa formulir permintaan asuransi merupakan dasar perjanjian dan formulir tersebut berisi keterangan atau jawaban yang benar atau menurut pengetahuan dan keyakinan tertanggung adalah benar adanya.

2. Implied Warranty

Dalam asuransi marine terdapat apa yang disebut dengan implied warranty bahwa kapal itu dalam kondisi laik laut dan semuanya memenuhi ketentuan (pasal 39 Marine Insurance Act 1906) ${ }^{20}$.

${ }^{20}$ Warranty of Seaworthines of Ship:

1. In a voyage policy there is an implied warranty that at the commencement of the voyage the ship shall be seaworthy for the purpose of the particular adventure insured.

2. Where the policy attaches while the ship is in port, there is also an implied warranty that she shall, at the commencement of the risk, be reasonably fit to encounter the ordinary perils of the port.

3. Where the policy relates to a voyage which is performed in different stages, during which the ship requires different kinds of or further preparation or equipment, there is an implied warranty that at the commencement of each stage the ship is seaworthy in respect of such preparation or equipment for the purposes of that stage.

4. A ship is deemed to be seaworthy when she is reasonably fit in all respects to encounter the ordinary perils of the seas of the adventure insured.

5. In a time policy there is no implied warranty that the ship shall be seaworthy at any stage of the adventure, but where, with the privity of the assured, the ship is sent to sea in an unseaworthy state, the insurer is not liable for any loss attributable to unseaworthiness. 
Secara umum implied warranty tidak terdapat dalam jenis asuransi lain selain asuransi marine.

Selain itu, dalam hal terjadi kerugian yang dapat menimbulkan klaim pada polis, terdapat beberapa kewajiban yang harus dilakukan oleh pihak tertanggung. Kewajiban tersebut adalah:

\section{Implied Duties}

Menurut hukum dalam hal terjadi suatu kerugian, tertanggung harus bertindak seolah-olah ia tidak mengasuransikan obyek yang mengalami kerugian itu dan ia memiliki kewajiban untuk mengambil langkah-langkah yang pantas untuk meperkecil kerugian tersebut. Walaupun kewajiban tersebut tidak tertulis di dalam polis, akan tetapi pihak tertanggung harus melakukan kewajiban tersebut.

2. Express Duties

Setiap kejadian yang memungkinkan terjadinya klaim pada polis harus segera diberitahukan kepada pihak penanggung dan keterangan lengkap mengenai kerugian tersebut harus disampaikan kepada pihak penanggung dalam suatu periode tertentu yang ditetapkan dalam polis.

3. Proof of Loss

Dalam hal terjadi suatu kerugian, tertanggung berkewajiban untuk membuktikan:

a. Bahwa ia telah mengalami kerugian karena suatu kejadian atau peristiwa yang dijamin dalam polis;

b. Nilai atau jumlah kerugian tersebut.

Akan tetapi, jika pihak penanggung berpendapat bahwa kerugian tersebut disebabkan oleh suatu bahaya yang dikecualikan oleh polis, maka pihak penanggung wajib membuktikan hal tersebut.

\section{E. Tanggung Jawab Penanggung/Perusahaan Asuransi (Ceding Company) Terhadap Tertanggung}

Perusahaan asuransi sebagai penanggung pertama merupakan sebuah perusahaan yang dengan sengaja menyediakan diri untuk mengambil alih dan menerima risiko pihak lain (tertanggung) melalui perjanjian asuransi. Keadaan ini mengakibatkan posisi perusahaan asuransi sebagai penanggung pertama berada dalam posisi yang cukup serius. Di satu sisi, perusahaan asuransi menanggung beban sendiri karena kegiatannya menjalankan jasa asuransi, kemudian di sisi lain perusahaan asuransi juga memiliki tanggung jawab terhadap 
kewajiban-kewajibannya yang harus dipenuhi terhadap pihak tertanggung dalam menjalankan perjanjian asuransi.

Perusahaan asuransi sebagai penanggung pertama juga memiliki masalah yang sama dengan pihak tertanggung, yaitu risiko terhadap konsekuensi keuangan tertentu karena terjadinya suatu peristiwa yang belum pasti terjadi. Konsekuensi keuangan yang timbul tersebut belum tentu dapat diatasi dan dipikul sendiri. Oleh karena itu, penyebaran dan peralihan risiko merupakan salah satu upaya untuk mengatasi konsekuensi tersebut. Pada umumnya, penanggung menempuh salah satu upaya yang efektif untuk mengatasi kesulitan-kesulitan tersebut dengan cara melakukan perjanjian reasuransi dengan pihak penanggung ulang karena reasuransi dapat melaksanakan fungsi mengalihkan dan menyebarkan risiko.

Adanya peranan reasuransi yang mempunyai jangkauan luas tersebut memungkinkan perusahaan asuransi makin mengembangkan fungsinya sebagaimana seharusnya sesuai dengan poisisinya sebagai penanggung pertama. Perusahaan asuransi dapat menutup perjanjian asuransi yang bervariasi dan mencakup jenis asuransi yang luas. Dengan demikian, tujuan perusahaan dapat diacapai sampai pada batas maksimum yang mungkin dapat dicapai dengan aman. Jadi secara luas, tujuan reasuransi adalah tidak lain untuk menyebarkan risiko, dengan kata lain untuk membagikan tanggung jawab penanggung pertama kepada penanggung ulang.

Perusahaan asuransi sebagai suatu perusahaan yang menawarkan jasa proteksi, akan berusaha untuk dapat menampung semua permintaan sebanyak daya tampung atau kepastiannya secara maksimal. Perusahaan asuransi juga berusaha secara intensif agar dapat menghasilkan pemasukan secara maksimal dengan maksud untuk menggalang keuntungan yang maksimal pula. Untuk itu perusahaan asuransi mengadakan suatu sistem pemasaran untuk memajukan usahanya. Pemasaran tersebut dapat dilakukan dengan 2 macam cara, adalah:

1. Melalui penawaran umum dengan menggunakan sarana media cetak, media visual maupun cara-cara pendekatan massa yang lain;

2. Melalui penawaran terbatas, antara lain menggunakan sistem relasi, hubungan kerja melalui jalur formal maupun tidak formal.

Kegiatan penyediaan jasa proteksi yang dilakukan oleh perusahaan asuransi tersebut tidak pernah luput dari kerugian yang 
akan diderita oleh perusahaan asuransi yang dikarenakan ketidakmampuan perusahaan asuransi untuk melaksanakan kewajibannya yaitu mengganti kerugian yang diderita oleh pihak tertangung. Ketidakmampuan perusahaan asuransi dalam melaksanakan kewajibannya tersebut dapat mengakibatkan pembekuan usaha berupa kepailitan dan likuidasi.

Hal ini tentu saja akan merugikan pihak tertanggung. Untuk mengatasi masalah tersebut, maka pemerintah membuat suatu peraturan untuk melindungi pihak tertanggung dari kerugian yang dideritanya. Oleh karena itu, untuk mengantisipasi hal tersebut, perusahaan asuransi diwajibkan memiliki cadangan teknis sesuai dengan aturan pasal 14 ayat (1) PP No. 73 Tahun 1992 tentang Penyelenggaraan Usaha Perasuransian ${ }^{21}$ untuk memenuhi kewajibannya kepada tertanggung.

Cadangan teknis tersebut dapat diartikan sebagai dana yang harus disisihkan untuk memenuhi kewajiban kepada tertanggung atau pemegang polis. Cadangan teknis ini pada umumnya dibagi menjadi 4 macam, adalah:

1. Cadangan premi yang belum merupakan pendapatan (unearned premium reserve) yang diatur dalam pasal 22 ayat (1) KMK No. 224 Tahun $1993 ;^{22}$

2. Cadangan klaim (outstanding claim reserve) yang diatur dalam pasal 23 ayat (1) huruf a, b, c KMK No. 224 Tahun $1993 ;^{23}$

${ }^{21}$ Setiap perusahaan asuransi dan perusahaan reasuransi harus membentuk cadangan ekenis asuransi sesuai dengan jenis asuransi yang diselenggarakan, yaitu:

a. Cadangan teknis asuransi kerugian, terdiri dari cadangan atas premi yang belum merupakan pendapatan dan cadangan klaim.

b. Cadangan teknis asuransi jiwa, terdiri dari cadangan premi, cadangan premi anuitas, cadangan atas premi yang belum merupakan pendapatan dan cadangan klaim.

${ }^{22}$ Cadangan atas premi yang belum merupakan pendapatan untuk asuransi kerugian dihitung dengan cara harian dikurangi bagian yang direasuransikan untuk setiap polis.

${ }^{23}$ Perhitungan cadangan klaim asuransi kerugian harus mencakup:

a. Jumlah klaim yang telah disepakati tapi belum dibayar, berikut jasa penilai kerugian dikurangi beban klaim yang menjadi bagian penanggung ulang.

b. Perkiraan wajar atas setiap klaim dalam proses penyelesaian berikut biaya jasa penilai kerugian dikurangi beban klaim yang menjadi bagian penanggung ulang.

c. Perkiraan wajar atas setiap klaim yang mungkin sudah terjadi tapi belum dilaporkan (IBNR) berikut biaya jasa penilai kerugian dikurangi beban klaim yang menjadi bagian penanggung ulang. 
3. Cadangan klaim IBNR (Incurred But Not Reported);

4. Cadangan katastropa (catasthrope claim reserve).

Apabila terjadi pembekuan usaha/pencabutan izin usaha terhadap perusahaan asuransi yang dilakukan oleh Menteri Keuangan seperti yang tercantum dalam pasal 17 UU No. 2 Tahun 1992 tentang Usaha Perasuransian sebagai berikut:

1. Dalam hal terdapat pelanggaran ketentuan dalam UndangUndang ini atau peraturan pelaksanaannya, Menteri dapat melakukan tindakan berupa pemberian peringatan, pembatasan kegiatan usaha, atau pencabutan izin usaha.

2. Tindakan sebagaimana dimaksud dalam ayat (1) ditetapkan dengan tahapan pelaksanaan adalah:

a. Pemberian peringatan;

b. Pembatasan kegiatan usaha;

c. Pencabutan izin usaha.

3. Sebelum pencabutan izin usaha,Menteri dapat memerintahkan perusahaan yang bersangkutan untuk menyusun rencana dalam rangka mengatasi penyebab dari pembatasan kegiatan usahanya.

4. Tata cara pelaksanaan ketentuan sebagaimana dimaksud dalam ayat (1) serta jangka waktu bagi perusahaan dalam memenuhi ketentuan sebagaimana dimaksud dalam ayat (3) diatur dengan Peraturan Pemerintah.

maka kerugian pihak tertanggung tetap terlindungi dengan adanya pengaturan dalam pasal 20 ayat (2) UU No. 2 Tahun 1992 tentang Usaha Perasuransian yang menyatakan bahwa hak pemegang polis atas pembagian harta kekayaan perusahaan asuransi kerugian atau perusahaan asuransi jiwa yang dilikuidasi merupakan hak yang utama.

\section{F. Claim Cooperation Claused dalam Perjanjian Reasuransi}

Dalam perjanjian reasuransi yang dilakukan di antara perusahaan asuransi/penanggung (ceding company) dengan perusahaan reasuransi/ penanggung ulang, dikenal adanya suatu klausula yang biasa disebut dengan claim cooperation clause.

Claim cooperation clause dapat diartikan sebagai suatu klausula dalam perjanjian reasuransi dimana ditentukan bahwa ceding company harus selalu bekerjasama dengan (memberitahukan kepada) penanggung ulang mengenai langkah-langkah penting yang akan 
dilakukannya dalam melaksanakan proses klaim dan merundingkan keputusan dengan penanggung ulang mengenai besarnya jumlah klaim yang akan dibayar. ${ }^{24}$ Selain merundingkan penyelesaian klaim, biasanya dalam claim cooperation clause juga dicantumkan perihal mengenai penunjukkan lost adjuster untuk menaksir besarnya jumlah klaim yang harus dibayar oleh penanggung.

Pelanggaran yang dilakukan oleh pihak penanggung (ceding company) terhadap klausula ini termasuk ke dalam bentuk wanprestasi, sehingga pihak penanggung ulang dapat menuntut ceding company untuk melakukan hal-hal sebagai berikut:

1. Pemenuhan perjanjian;

2. Pemenuhan perjanjian disertai ganti rugi;

3. Ganti rugi saja;

4. Pembatalan perjanjian;

5. Pembatalan perjanjian disertai ganti rugi.

Akan tetapi dalam praktiknya, hal seperti ini jarang terjadi. Kalaupun hal ini terjadi, biasanya pihak penanggung ulang tidak terlalu menghiraukan hal tersebut karena hal ini bukan merupakan suatu masalah yang besar. Hal ini sudah merupakan sesuatu yang dianggap wajar dalam perjanjian reasuransi. Dalam praktik, pelanggaran terhadap claim cooperation clause tidak terlalu dipersoalkan karena hal ini menyangkut hubungan kerjasama diantara perusahaan asuransi dengan perusahaan reasuransi yang sudah lama terjalin dan hubungan tersebut akan terus berlanjut selama perusahaan asuransi dan perusahaan reasuransi saling membutuhkan satu sama lain. ${ }^{25}$

\section{Penutup}

\section{A. Kesimpulan}

Dari pokok permasalahan yang telah dibahas pada bab-bab sebelumnya, maka kesimpulan yang dapat ditarik adalah sebagai berikut:

24 Safri Ayat, Op. Cit., hal. 88.

${ }^{25}$ Wawancara dengan Bapak Cendekiawan, S.H., Kepala Seksi Klaim Varia PT. Nasional Re, di Jakarta, yang dilakukan pada tanggal 18 Desember 2008. 
Pertama, bentuk perlindungan hukum bagi pihak tertanggung (nasabah) apabila terjadi sanksi berupa pembekuan usaha oleh pihak regulator terhadap perusahaan asuransi yang memberikan proteksi terhadap obyek asuransinya adalah penggantian ganti kerugian yang dilakukan oleh pihak penanggung/perusahaan asuransi sesuai dengan ketentuan pasal 20 ayat (1) UU No. 2 Tahun 1992 tentang Usaha Perasuransian yang menyatakan bahwa hak pemegang polis atas pembagian harta kekayaan perusahaan asuransi kerugian atau perusahaan asuransi jiwa yang dilikuidasi merupakan hak yang utama.

Kedua, pelanggaran pihak penanggung (ceding company) terhadap claim cooperation clause dapat dikategorikan sebagai wanprestasi yang diatur dalam KUHPerdata. Akan tetapi pada praktiknya hal ini jarang terjadi dan jika terjadi, hal ini merupakan sesuatu yang wajar sehingga hal ini tidak terlalu dipermasalahkan oleh kedua belah pihak

\section{B. Saran}

Saran dari penulis mengenai permasalahan ini yaitu sebagai berikut:

Pertama, adanya peraturan baru yang jelas memuat pengaturan lebih lanjut mengenai permasalahan penanganan klaim.

Kedua, adanya suatu lembaga khusus yang dapat melindungi hakhak nasabah sebagai konsumen dalam bidang jasa perasuransian. 


\section{Daftar Pustaka}

\section{Buku}

Ayat, Safri. Pengantar Reasuransi, Jakarta: Akademi Asuransi Trisakti, 2000.

Carter, R.L. Reinsurance, London: Kluwer Publishing Limited, 1979.

Dwiharsono, Sonni. Prinsip-prinsip dan Praktek Asuransi (PK.001), Jakarta: Jakarta Insurance Institute (JII), 1991.

Gerathewohl, Klaus, Reinsurance Principles and Practice vol. II, Karlsruhe: Verlag Versicherungs Wirtschaftt C.V, 1982

Goenka, Ashok. Practical Aspects of Insurance, Singapore: Singapore College of Insurance, 2003.

Hartono, Sri Rejeki. Hukum Asuransi dan Perusahaan Asuransi, Jakarta: Sinar Grafika, 1995.

Kaihatu, J. E. Asuransi Pengangkutan, Cet.III. Jakarta: Djambatan, 1970.

Mamudji, Sri dan Hang Rahardjo. Teknik Menyusun Karya Tulis Ilmiah, Jakarta, 2005.

Simanjuntak, Emmy Pangaribuan. Asuransi Pengangkutan, Yogyakarta: Seri Hukum Dagang Fakultas Hukum Universitas Gadjah Mada, 1975.

Soekanto, Soerjono dan Sri Mamudji. Penelitian Hukum Normatif Suatu Tinjauan Singkat, Jakarta: Rajawali Pers, 2004.

Subekti. Hukum Perjanjian, Jakarta: Intermasa, 1987.

Suryodiningrat, R.M. Azas-azas Hukum Perikatan, Bandung: Tarsito, 1982.

\section{Peraturan Perundang-Undangan}

Undang-Undang No. 2 Tahun 1992 tentang Usaha Perasuransian, LN No. 2 Tahun 1992, TLN No. 2907.

Peraturan Pemerintah Republik Indonesia Tentang Penyelenggaraan Usaha Perasuransian. PP No. 73 Tahun 1992.

Departemen Keuangan, Keputusan Menteri Keuangan Republik Indonesia Tentang Kesehatan Perusahaan Asuransi dan Perusahaan Reasuransi. KMK No. 224/KMK. 017/1993. 
Keputusan Menteri Keuangan Republik Indonesia Tentang Kesehatan Perusahaan Asuransi dan Perusahaan Reasuransi. KMK No. 481/KMK. 017/1999.

Kitab Undang-Undang Hukum Dagang dan Undang-Undang Kepailitan (Wetboek van Koophandel en Faillissements-Verordening). Cet.18. Jakarta: Pradnya Paramita, 1989.

Kitab Undang-Undang Hukum Perdata (Burgerlijk Wetboek), Diterjemahkan oleh R. Subekti dan R. Tjitrosudibio. Edisi Revisi. Cet. 33. Jakarta: Pradnya Paramita, 2003. 